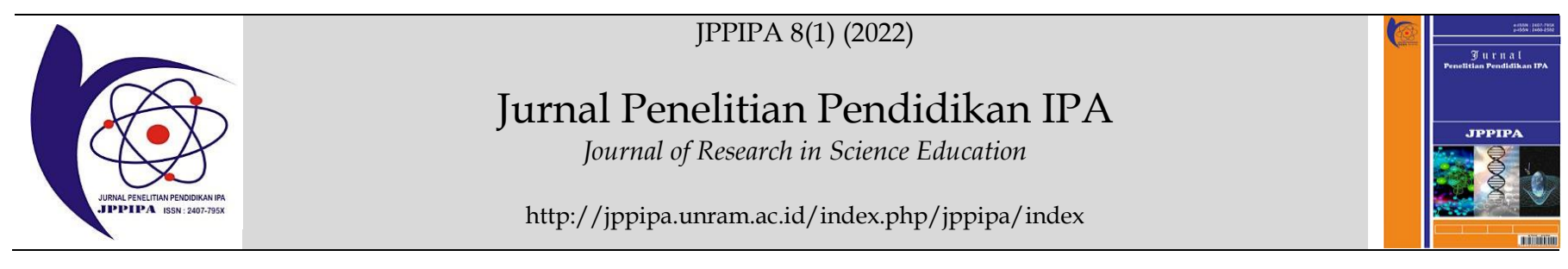

\title{
The Effect of Applying Blended Learning Strategies Flipped Classroom Model on Students' Critical Thinking Skills
}

\author{
Zulhamdi ${ }^{1}$, Hafnati Rahmatan², Wiwit Artika ${ }^{3}$, Andi Ulfa Tenri Pada ${ }^{4}$, Ismul Huda ${ }^{5}$ \\ ${ }^{1}$ Master of Biology Education, Faculty of Teacher Training and Education, Syiah Kuala University, Banda Aceh, Indonesia.
}

DOI: $\underline{10.29303 / j p p i p a . v 8 i 1.1186}$

\section{Article Info}

Received: November 29, 2021

Revised: Januari 2, 2022

Accepted: January 7, 2022

Published: January 31, 2022

\begin{abstract}
Critical thinking skills are competencies that are expected to be possessed by every student in 21st century learning. One of the efforts that can be made to improve students' critical thinking skills is to apply the flipped classroom learning model. This study aims to determine the effect of students' critical thinking skills through the application of the blended learning model of the flipped classroom. The research approach used is quantitative with a quasi-experimental type of research, the research design used is pretest-posttest nonequivalent control group design. Sampling used a total sampling technique from the entire population of 102 students of class XI IPA at SMAN 1 Peulimbang. The instrument used to measure critical thinking skills is in the form of essay questions accompanied by an assessment rubric. Data on critical thinking skills were analyzed by parametric statistics using the independent sample $t$ test. The results showed that the value of $<0.05$, then there was an effect of students' critical thinking skills after the application of the blended learning model of the flipped classroom on the respiratory system material.
\end{abstract}

Keywords: Blended Learning; Flipped Classroom; Critical Thinking Skills

Citation: Zulhamdi, Z., Rahmatan, H., Artika, W., Pada, A. U.T., \& Huda, I. (2022). The Effect of Applying Blended Learning Strategies Flipped Classroom Model on Students' Critical Thinking Skills. Jurnal Penelitian Pendidikan IPA, 8(1), 8693. https://doi.org/10.29303/jppipa.v8i1.1186

\section{Introduction}

Organ system is one of the learning topics in class $X I$ in the even semester. One of them discusses the respiratory system with basic competence analyzing the relationship between the structure of the organs that make up the respiratory system in relation to bioprocesses and functional disorders that can occur in the respiratory system (Basic Competencies 3.8), presenting the results of an analysis of the effect of air pollution on abnormalities in the structure and function of the respiratory system function of human respiratory organs based on a literature study (Basic Competencies 4.8 ), with several learning objectives that must be achieved.

Achievement of the learning objectives of the respiratory system material in SMA Negeri 1 Peulimbang, Bireuen Regencynot achieved optimally, this is influenced by several factors, including the lack of advanced teaching materials. This factor is very influential on students' mastery of concepts in the respiratory system material, because students have only studied material available at school in the form of textbooks. These problems have an impact on student learning outcomes on the respiratory system material, so that it can result in a lack of student understanding of the material.

Based on the data obtained from initial observations, it is known that the learning outcomes of students in SMA Negeri 1 Peulimbang, Bireuen Regency in biology lessons on the respiratory system material are low learning outcomes students can be seen from the average initial test scores of students on the respiratory system material that is still below the minimum completeness criteria, which is $60 \%$ of students with a minimum completeness criteria of 75 . The level of

\footnotetext{
*E-mail: hafnati_rahmatan@unsyiah.ac.id
} 
competency achievement that has not been optimal can be used as an alternative reflection that the level of competence and relevance learning also needs to be taken seriously. Data on student learning outcomes at SMA Negeri 1 Peulimbang, Bireuen Regency for the last three years have averages, namely: (1) 2016/2017 academic year an average of 66.79 ; (2) The academic year 2017/2018 obtained an average score of 66.83; and (3) the 2018/2019 academic year is 66.87 (SMA 1 Peulimbang, 2019).

Based on the results of interviews with one of the biology teachers at SMA Negeri 1 Peulimbang, Bireuen Regency, information was obtained that students still did not understand the material of the respiratory system. This is because the learning process is still centered on the teacher while students only listen and pay attention to the teacher's explanation. Many students are able to present a good level of memorization of the subject matter they receive, but in reality, do not understand it (Utami, et al., 2021). And students have difficulty understanding concepts as they are usually taught, namely by using an abstract combined with the lecture method (Asifah, 2013). Research on critical thinking skills has been carried out by several previous researchers,

As stated in the 21st century learning objectives, critical thinking is a competency that is expected to be possessed by every student. In line with this opinion. Ennis (2018) said that critical thinking is a reasonable or reason-based reflective way of thinking that is focused on determining what to believe and do. One of the efforts that can be made to improve learning outcomes and critical thinking skills of students is to provide good and appropriate learning facilities in the form of blended learning strategies that have convenience, which can be done not only through a face-to-face process, but also through a face-to-face process through the internet.

Blended learning strategy is a new concept in learning where the delivery of material can be done in class and online. A well-done combination of face-toface teaching where teachers and students meet face-toface and through online media that can be accessed at any time. The combination of face-to-face learning with e-learning is due to the limited time and it is easy to make students feel bored quickly in the learning process and the demands of increasingly widespread technological developments (Wardani et al., 2018).

The flipped classroom model is a learning model in which students before studying in class are required to study the material first at home according to the assignments given by the teacher Nofrion (2019). In the opinion, flipped classroom is a learning model in which the teacher delivers material in class and then it is followed by assignments at home, so in this flipped classroom, the teacher gives assignments to students to learn the material to be studied. This learning is supported by various e-learning applications, one of which is the Microsoft Teams (MT) application. This application can be used by students and teachers when outside the classroom.

MT is a unified communication and collaboration platform that combines the features of work conversations, video meetings, file storage, and application integration. MT provides several interesting features to support learning in this virtual class, such as Microsoft Outlook, OneDrive, Teams, Microsoft Forms, Microsoft Word, Excel, Power Point, and Sway (TSM Lecturer Team, 2020). A study on the application of MT applications in the learning process was conducted by Putri, et al., (2021) who stated that the learning interest of students who used MT based blended learning strategies was higher than the learning interests of students who only used conventional learning strategies.

Many studies on blended learning have been carried out (Jong, 2016). The study showed a significant change in the respondent's memory with the provision of new learning obtained from the application of the blended learning strategy. The implementation of the blended learning strategy is also expected to help teachers and students in an effort to improve students' critical thinking skills. However, blended learning users with MT applications have not been widely published, so further exploration is needed regarding its application in the learning process.

It is important that this research is carried out so that the problem of the level of achievement of competence, ability, critical thinking and time allocation can be overcome by using MT media. This media can display respiratory system material clearly with pictures and videos, then for time efficiency can take advantage of the flipped classroom blended learning strategy which is able to combine offline and online learning processes. This learning strategy is more flexible in its application because it can also be applied online so that students can deepen their understanding of the material independently so that it is expected to improve learning outcomes and critical thinking skills.

\section{Method}

The approach used in this study is a quantitative approach, the type of research used is applied research using quasi-experimental methods. The design used in this study was Pretest-Posttest Non-Equivalent Control group design. The learning process takes place on the respiratory system material by applying the flipped classroom blended learning strategy in the experimental group and conventional learning in the control group. The population in this study were all students of class XI 
IPA SMA Negeri 1 Peulimbang, Bireuen Regency, totaling 106 students.

Sampling was done by purposive sampling technique, which is a random sampling technique between all students of class XI IPA SMA Negeri 1 Peulimbang, then taking two classes that have homogeneous average values after being given a pretest to be used as an experimental class and a control class. The number of samples is 102 students from the total population taken from the 2 homogeneous classes.

The data collection instrument to determine critical thinking skills is in the form of a test set in the form of an essay question accompanied by a rubric. Previously, the question had been validated by the validator. After validation, the test instrument was carried out field trials with content validity techniques to find the level of validity, difficulty of the questions, and differentiating power. The test instrument trials were carried out on class XII students who had studied the respiratory system material. So that the obtained rSpearman $=0.84$ which means the reliability of the test items is high.

Data collection techniques for critical thinking skills and student learning outcomes are in the form of pretest and posttest, then the data will be calculated normalized gain score using the formula from Meltzer (2002). Prior to the t-test, prerequisite tests were conducted, namely the normality test and homogeneity test between the experimental class and the control class. After the data was tested with normality and homogeneity, then a hypothesis test was conducted between two different variables with the help of the SPSS 23.0 for windows program, to test the hypothesis. (If the data is normally distributed and the data variation is homogeneous) then a parametric test is carried out using the Independent Sample T-test test formula, however (if the data is not normally distributed and the data variation is not homogeneous) then a nonparametric test is carried out, namely the Mannwhitney test.

\section{Results and Discussion}

The results of research on critical thinking skills including the average score of N-Gain critical thinking skills of students in the experimental class and control class can be seen in Table 1 .

Table 1. The results of the average $\mathrm{N}$-gain test of students' critical thinking skills in the experimental class and control class.

\begin{tabular}{lrrrr}
\hline Class & Average & Normality $\left.^{*}\right)$ & $\begin{array}{l}\text { Homoge- } \\
\text { neity }\end{array}$ & $\left.\begin{array}{l}\text { Signifi- } \\
\text { cance }\end{array}{ }^{* * *}\right)$ \\
\hline Experiment & 84.68 & 0.200 & 0.123 & 0.000 \\
Control & 61.66 & 0.140 & & \\
\hline
\end{tabular}

Description:

*) = Kolmogorov-Smirnov Test (Normal, $>0.05$ )

**) = Levene Test (homogeneous, $>0.05$ )

${ }^{* *} \quad=$ Independent Sample t-Test (Significant, < 0.05)

The test results of the difference between the two averages show the Asymp value Sig. (2-tailed) $=0.000$, which indicates that the value of Sig. is smaller than 0.05 . This means that the N-gain score of the critical thinking skills of experimental class students who received learning using the flipped classroom blended learning strategy was better than control class students who received conventional blended learning strategies. Thus there is an effect of using flipped classroom blended learning strategy to students' critical thinking skills at SMA Negeri 1 Peulimbang.

Table 1. shows that the significant value obtained is smaller than the value of $\alpha=0.05$ so that the conclusion obtained is an increase in critical thinking learners who learns flipped classroom blended learning strategy better than learners who received ordinary learning. This is in accordance with the opinion Nurhayati, et al (2019), implementation flipped classroom blended learning strategy effective in improving critical thinking skills learners.

Similar research results were also obtained by Maolidah, et al (2017) that the application flipped classroom blended learning strategy there is a process of interaction between learners, teachers and learning environment that produces changes in behavior, learning outcomes, and students' thinking abilities. Thus the hypothesis is answered that there is an effect of using flipped classroom blended learning strategy on the thinking skills of students at SMA Negeri 1 Peulimbang.

Analysis Critical thinking skills pretest, posttest and N-Gain of control class and experimental class students as a whole are presented in Figure-1.

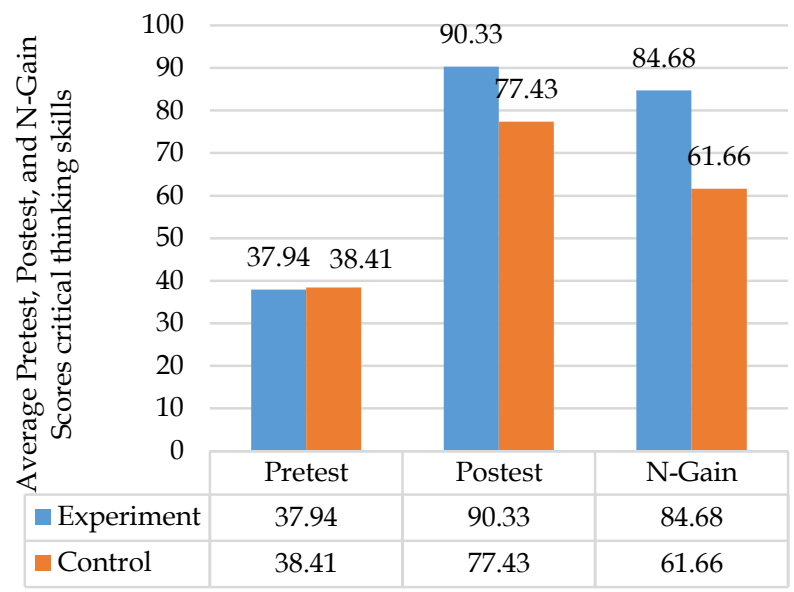

Figure 1. Average Pretest, Posttest and N-Gain scores Students' Critical Thinking Skills 
Figure 1 shows that the mean difference critical thinking skills pretest, posttest and N-Gain participants. The mean N-Gain of experimental class learning outcomes was 84.68 and control 61.66. The improvement of students' critical thinking skills is analyzed through the N-Gain formula by Meltzer (2002). Improvement test results students' critical thinking skills in Table 2.

Table 2. Descriptive statistics Critical Thinking Skills Students of Experiment Class and Control Class at SMA Negeri 1 Peulimbang

\begin{tabular}{llrrr}
\hline Value & Class & $\mathrm{N}$ & Average & Std. Deviation \\
\hline Pretest & Experiment & 51 & 37.94 & 12.54 \\
& Control & 51 & 38.41 & 12.75 \\
Posttest & Experiment & 51 & 90.33 & 8.65 \\
& Control & 51 & 77.43 & 6.10 \\
\multirow{2}{*}{ N-Gain } & Experiment & 51 & 84.68 & 13.55 \\
& Control & 51 & 61.66 & 13.01 \\
\hline
\end{tabular}

Table 2 shows descriptive statistics of critical thinking skills of students in the experimental class and control class at SMA Negeri 1 Peulimbang. Average NGaincritical thinking skills $85 \%$ of experimental class students and $62 \%$ control class it also shows that there is a big difference.

Improvement of each indicator of critical thinking skills students consisting of simple explanations, basic skills, conclusions, advanced explanations, strategies and tactics in the experimental class and control class are presented in Figure 2.

$$
\text { - Control } \quad \text { Experiment }
$$

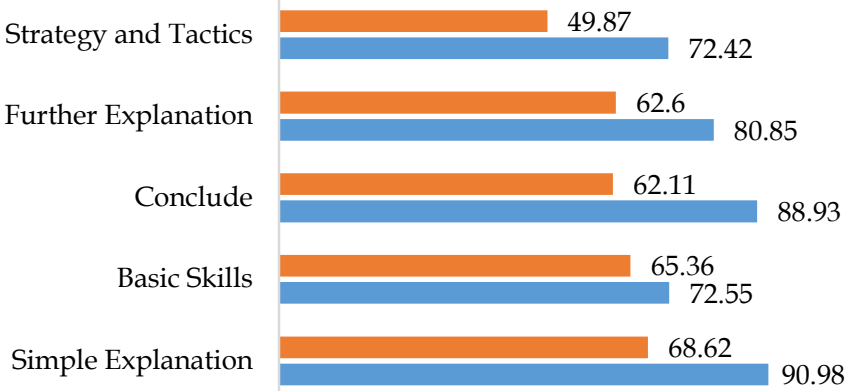

Figure-2. Average N-Gain Critical Thinking Skills Experimental and Control Class Students Per Indicator

Based on Figure 2, the overall indicators of students' critical thinking skills in general in the two groups increased, but the indicators that experienced a significant increase were simple explanations. The ability to think critically on indicators of simple explanations increases due to the application of blended learning strategies the flipped classroom model provides opportunities for students to study material, analyze arguments that are usually presented in class, turn into student assignments that must be studied at home and students at school only do their homework. Assignments or confirming the knowledge they learn at home with their friends and teachers at school. In this aspect, students experience the process of analyzing arguments by investigating a reason to find out the real situation.

Johnson (2007) in Naja, et al., (2020)said critical thinkers examine their own thought processes and the thought processes of others to see if their thinking processes make sense. The dialectical process in the brain carried out by students makes students think, read an opinion and translate it into their respective languages to be able to explain in simple terms what they know in writing.

In line with opinion Wahyuni (2015)One of the characteristics of people who have critical thinking is that they are able to think fairly and reflectively through an emphasis on making decisions about what to believe and do. This supports flipped classroom learning because the fipped classroom learning model allows for transitions to assessment questions and activities that focus on critical thinking skills while also increasing final grades greater than the traditional model (Deruisseau, 2016)

Skills think critically on indicators of building basic skills also increase due to using the application of learning strategies blended learning in the flipped classroom model, students are able to think regularly to be able to use their thinking power so that they can think carefully about a source by considering the criteria of a source. From this situation, students explore information by understanding events related to what they are experiencing, and connecting them with sources obtained and anticipating information by using their way of thinking and maximizing direct and indirect observations then think carefully good observations to be used as an opinion. From the knowledge and experience that occurs to students, it becomes the basis so that they can provide a reason. To make it better when giving an excuse.

In line with Koh et al., (2008) conveyed that emotions are very important because when emotions are stable, critical thinking will also be good. So that it can express the reasons sensibly according to the context. Research conducted by Hantla (2014) that the flipped classroom model provides more space and critical thinking paradigms that are complex and involve good student social interactions that make classrooms innovative and independent.

Skills think critically on Conclusion indicators also increase because by using the application of blended learning strategies the flipped classroom model provides opportunities for students to interpret, draw conclusions and consider to determine the results of 
their considerations. Stating interpretation is a deductive way of thinking which in its delivery requires a good knowledge and experience, so that in presenting a provisional conclusion it must be with a deep understanding based on a background of facts and good sources. Johnson (2007) said that only critical thinking allows students to analyze their own thinking to ensure that they have made choices and drawn conclusions.

In line with Sofya et al., (2020) suggested that the flipped classroom could be applied to improve critical thinking through activities outside and inside the classroom. When students carry out activities, they can explore various learning resources such as videos, power points, e-books, and scientific articles. In class, students follow the learning process to deepen and conclude understanding of the material through discussion and problem solving in order to improve critical thinking skills.

Skills think critically on indicators for making further explanations also increase due to using the application of learning strategies blended learning in the flipped classroom model, students develop their thinking skills in understanding the meaning of a term to become a further experience. In this case students are very good at identifying terms but still have a lot of practice when identifying assumptions by constructing an argument. Students are not optimal in doing so because they identify assumptions because an assumption can only be accepted if it is clear, logical, and based on extensive experience. Like intelligence is a camera lens that focuses sharply while wisdom is a wide angle lens (Farisi, et al., 2017). This means that the assumptions are clear, logical, conditional with good experience, students build a good opinion if they are accompanied by wisdom.

In line with Roudlo (2020)explained that by using flipped classroom learning, students were able to cultivate critical thinking skills and independent learning of students. This is supported in learning activities using a flipped classroom where in these learning activities students are required to understand the material they are studying independently and find their own sources of knowledge that can help students understand the material they are studying.

Skills think critically on indicators of strategy and tactics also increase due to using the application of learning strategies blended learning in the flipped classroom model, students decide an action by considering possible solutions to what they are facing, students do based on information and experiences they have from daily life interactions. So that students can make excellent decisions and students are fully convinced to believe in an outcome and set it in action. Because students have gone through everyday knowledge and experience and often interact with others, it becomes a good experience value in thinking. Ozdamli \& Asiksoy (2016) stated that interactive activities carried out during the flipped classroom, teachers and students face to face directly in the classroom with a humanist approach to learning.

Previous research using flipped classroom ever done by Suo \& Hou (2017) which revealed that the design and implementation of an effective flipped classroom strategy will increase students' motivation, critical thinking skills, cooperative skills, and creative power. De Grazia, et al., (2012) noted that students given an optional video lecture came to class much more prepared than when they had been given textbook reading.

This finding is in line with the results of research conducted by Turan \& Goktas (2016)which states that students taught by flipped classroom have higher learning achievement and lower cognitive load than students taught by traditional learning. Similar research results were also obtained by Zhang \& Wu (2016) that students who are taught by flipped classroom have higher learning achievement than students who are taught by conventional learning. One of the most important abilities that affect student learning achievement is conceptual understanding so that high learning achievement can provide an illustration that students' conceptual understanding is also high.

The understanding of the respiratory system concept of students in the experimental group is higher than the control group because in the implementation of the learning process students have more opportunities to express the concepts they have learned in their own words, identify examples of concepts and apply them to solve a problem through learning steps with the flipped classroom learning model. With this approach the learning process is not confined to the classroom, students receive learning materials and practice questions outside of school and focus on classroom activities to discuss and discuss things they do not understand. This approach makes students have more study time and students can adjust their learning time and learning speed. This makes the teaching and learning process in the classroom more effective because students become more active in learning so that it has an impact on students' understanding of concepts.

In line with the research conducted Sajid et al., (2016) which states that blended learning flipped classroom model facilitate productive discussion and enhance learner interaction during valuable class time, enhancing their ability to reason and apply learned information.

The flipped classroom approach is a learning approach that divides two types of learning, namely prelearning and classroom learning. At the time of prelearning or before learning in class, students have 
received material exposure through learning modules and videos uploaded by teachers in MT a week before learning in class. This requires students to learn independently and interpret the learning material that will be discussed in class so that students better understand the material and already have a stock of knowledge before the learning process in class which makes the discussion process in class very effective.

This is in line with research from Merlin (2014) in Juniantari et al., (2019) which states that students have a positive perception of the addition of material through videos and exercises, with the flipped classroom learning, most of the students feel they understand the material better and assess that the video shared has helped their understanding of the material being studied. In addition, students who are not present in class do not miss the learning materials because they can get the material by watching the uploaded learning videos. After watching the learning video, students are asked to summarize and apply their understanding by doing practice questions according to their abilities.

Based on the results of the study, it is believed that the application of the flipped classroom blended learning strategy can make a significant contribution to improving learning outcomes and can increase students' critical thinking skills. The results of this study are in line with the results of the study Shabani \& Mohammadian (2014) which states that learning outcomes are influenced by several internal factors, namely factors that exist within individuals who are studying which include physical factors, such as health and psychological factors such as talents, interests, motivation, intelligence, thinking abilities and so on. So from this statement it can be concluded that increasing critical thinking skills will lead to increased learning outcomes. The relationship between critical thinking skills and student learning outcomes is also explained by Weissinger (2003) critical thinking related to thinking awareness self-reflection, basic skills, and willingness to ask questions in order to clarify and improve understanding which helps in drawing the right conclusions and making the best decisions.

\section{Conclusion}

Based on the results of research on the application of flipped classroom blended learning strategy on the respiratory system material at SMA Negeri 1 Peulimbang, Bireuen Regency, it can be concluded that: The use offlipped classroom blended learning strategy can affect critical thinking skills on the concept of the respiratory system.

\section{Acknowledgments}

The author would like to thank Mr. Hasan Basri, S.Pd., MM as the principal of SMA Negeri 1 Peulimbang and to Mrs. Rahmatul Hayati, S.Si as the representative of the curriculum and Mrs. Khairani, S.Pd.I and Mr. Munawir Sajali, S. Pd as a teacher in the field of biology who has helped in the smooth process of research.

\section{References}

Asifah, N. (2013). Pengembangan modul IPA terpadu kontekstual pada tema bunyi. Unnes Science Education Journal, 2(1):188-195. Retrieved from: https://journal.unnes.ac.id/sju/index.php/usej /article/view/1822

De Grazia, J. L., Falconer, J. L., Nicodemus, G., \& Medlin, W. (2012). Incorporating screencasts into chemical engineering courses. 2012 ASEE Annual Conference $\mathcal{E}$ Exposition, 25-762. Retrieved from: https:// peer.asee.org/21519

Dehghanzadeh, S., \& Jafaraghaee, F. (2018). Comparing the effects of traditional lecture and flipped classroom on nursing students' critical thinking disposition: A quasi-experimental study. Nurse Education Today, 71, 151-156. https://doi.org/10.1016/i.nedt.2018.09.027

DeRuisseau, L. R. (2016). The flipped classroom allows for more class time devoted to critical thinking. Advances in Physiology Education, 40(4), 522-528. https://doi.org/10.1152/advan.00033.2016

Ennis, R. H. (2018). Critical thinking across the curriculum: A vision. Topoi, 37(1), 165-184. https://doi.org/10.1007/s11245-016-9401-4

Farisi, A., Hamid, A., \& Melvina, M. (2017). Pengaruh Model Pembelajaran Problem Based Learning terhadap Kemampuan Berpikir Kritis dalam Meningkatkan Hasil Belajar Siswa pada Konsep Suhu dan Kalor. Jurnal Ilmiah Mahasiswa Pendidikan Fisika, 2(3), 283-287. Retrieved from: http://www.jim.unsyiah.ac.id/pendidikanfisika/article/view/4979

Hantla, B.F. (2014). The effects of flipping the classroom on specific aspects of critical thinking in a Christian college: A quasi-experimental, mixed-methods study. Southeastern Baptist Theological Seminary.

Jainal, S. \& Louise, Y.I.S. 2019. Macromedia flash based on guided inquiry in critical thinking skills as learning innovations. International Journal on New Trends in Education and Their Implications, 10(3):21-29. etrieved from: https://eric.ed.gov/?id=ED598375

Jong, J.P. (2016). the Effect of a Blended Collaborative Learning Environment in a Small ( $\mathrm{Spoc}$ ): a Comparison With. Journal of Baltic Science 
Education, 15(2), 194-203. etrieved from: https://www.proquest.com/docview/23437490 46?pq-origsite $=$ gscholar\&fromopenview $=$ true

Juniantari, M., Pujawan, I. G. N., \& Widhiasih, I. D. A. G. (2019). Pengaruh pendekatan flipped classroom terhadap pemahaman konsep matematika siswa SMA. Journal of Education Technology, 2(4), 197204. http://dx.doi.org/10.23887/jet.v2i4.17855

Koh, G.C.H., Khoo, H.E., Wong, M.L., \& Koh, D. (2008). The effects of problem-based learning during medical school on physician competency: a systematic review. Cmaj, 178(1), 34-41. https://doi.org/10.1503/cmaj.070565

Li, C., He, J., Yuan, C., Chen, B., \& Sun, Z. (2019). The effects of blended learning on knowledge, skills, and satisfaction in nursing students: A metaanalysis. Nurse Education Today, 82, 51-57. https://doi.org/10.1016/j.nedt.2019.08.004

Mahanal, S., Siti, Z., Ika, D.S., Tri, M.S., \& Nur, I. 2019. Ricosre: a learning model to develop critical thinking skills for students with different academic abilities. International Journal of Instruction, 12(2):417-434. Retrieved from: https://eric.ed.gov/?id=EJ1211048

Maolidah, I. S., Ruhimat, T., \& Dewi, L. (2017). Efektivitas penerapan model pembelajaran flipped classroom pada peningkatan kemampuan berpikir kritis siswa. Educational Technologia, 1(2). Retrieved from: https://ejournal.upi.edu/index.php/edutechnol ogia/article/view/9147

McCutcheon, K., O'Halloran, P., \& Lohan, M. (2018). Online learning versus blended learning of clinical supervisee skills with pre-registration nursing students: A randomised controlled trial. International Journal of Nursing Studies, 82, 30-39. https://doi.org/10.1016/j.ijnurstu.2018.02.005

Meltzer, D.E. (2002). The relationship between mathematics preparation and conceptual learning gains in physics: A possible "hidden variable" in diagnostic pretest scores. American Journal of Physics, 70(12), 1259-1268. https://doi.org/10.1119/1.1514215

Naja, F.Y., Mei, A., \& Sa'o, S. (2020). Proses Berpikir Kritis Siswa Dalam Memecahkan Masalah Matematika Realistik Materi Geometri Ditinjau Dari Gaya Belajar. Jupika: Jurnal Pendidikan Matematika, 3(2), 51-60. https://doi.org/10.37478/jupika.v3i2.670

Nofrion, N. (2019). Flip your classroom: Flipped Classroom Melalui Penerapan Model Pembelajaran Exo Olo Task. Padang: Universitas Negeri Padang.

Nurhayati, R., Waluya, S.B., \& Asih, T.S.N. (2019). Model Pembelajaran Inkuiri Blended Learning Strategi Flipped Classroom dengan Media Interaktif untuk Meningkatkan Kemampuan Berpikir Kritis. Prosiding Seminar Nasional Pascasarjana (PROSNAMPAS), 2(1), 278-285. Retrieved from: https://proceeding.unnes.ac.id/index.php/snpa sca/article/download/291/274

Ozdamli, F., \& Asiksoy, G. (2016). Flipped classroom approach. World Journal on Educational Technology: Current Issues, 8(2), 98-105. Retrieved from: https://www.ceeol.com/search/articledetail?id $=963677$

Putri, A.R., Fakhruddin, M., \& Yanuardi, M.H. (2021). Pengaruh Penggunaan Model Blended Learning Berbasis Microsoft Teams terhadap Minat Belajar Siswa pada Pembelajaran Sejarah di SMA Negeri 3 Bukittinggi. Jurnal Pendidikan Tambusai, 5(2), 3119-3128. Retrieved from: https://www.jptam.org/index.php/jptam/articl e/view/1350/1193

Roudlo, M. (2020). Kemampuan Berpikir Kritis dan Kemdirian Belajar Melalui Model Pembelajaran Flipped Classroom dengan Pendekatan STEM. Prosiding Seminar Nasional Pascasarjana (PROSNAMPAS), 3(1), 292-297. Retrieved from: https://proceeding.unnes.ac.id/index.php/snpa sca/article/download/602/520

Sajid, M.R., Laheji, A.F., Abothenain, F., Salam, Y., AlJayar, D., \& Obeidat, A. (2016). Can blended learning and the flipped classroom improve student learning and satisfaction in Saudi Arabia? International Journal of Medical Education, 7, 281. https://doi.org/10.5116/ijme.57a7.83d4

Shabani, M. B., \& Mohammadian, M. (2014). Relationship between goal orientation, critical thinking, meta-cognitive awareness and selfregulated learning of Iranian students. International Journal of Language Learning and Applied Linguistics World, 5(1), 403-418. Retrieved from: $\quad$ http://www.ikiu.ac.ir/publicfiles/profiles/items/5feae9075604522b47129f40e c848b5e.pdf

Sofya, R., Hayati, A.F., \& Syofyan, R. (2020). Flippedped Learning as a Strategy to Improve Students Higher Order Thinking:(A Quasi Experiment). 1st Progress in Social Science, Humanities and Education Research Symposium (PSSHERS 2019), 150-153. Atlantis Press. Retrieved from: https://www.atlantis press.com/article/125943621.pdf

Suo, J., \& Hou, X. (2017). A study on the motivational strategies in college English flipped classroom. English Language Teaching, 10(5), 62-67. Retrieved from: https:// eric.ed.gov/?id=EJ1140043

Suwono, H., Susanti, S., \& Lestari, U. (2017). Guided inquiry facilitated blended learning to improve metacognitive and learning outcome of high 
school students. Journal of Physics: Conference Series, 824(2017), 1-10. Retrieved from: https://iopscience.iop.org/article/10.1088/17426596/824/1/012068/meta

TSM Lecturer Team. (2020). Panduan Microsoft Teams. Jakarta: Trisakti School of Manajement. Retrieved from:

https://id.scribd.com/document/452443703/TS

M-Panduan-Penggunaan-Microsoft-Office-365-

$\underline{\mathrm{pdf}}$

Turan, Z., \& Goktas, Y. (2016). The Flipped Classroom: instructional efficency and impact of achievement and cognitive load levels. Journal of E-Learning and Knowledge Society, 12(4). Retrieved from: https://www.learntechlib.org/p/173672

Utami, L., Rahmatan, H., Hasanuddin, H., Nurmaliah, C., \& Khairil, K. (2021). Penerapan Model Introduction Connection Application Reflection Extention (ICARE) Dipadu Modul Pembelajaran Berbasis Konstruktivisme Untuk Meningkatkan Keterampilan Berpikir Kritis Dan Hasil Belajar Peserta Didik. Jurnal Pendidikan Sains Indonesia, 9(3), 471-481. https://doi.org/10.24815/jpsi.v9i3.21273

Vanslambrouck, S., Zhu, C., Lombaerts, K., Philipsen, B., \& Tondeur, J. (2018). Students' motivation and subjective task value of participating in online and blended learning environments. Internet and Higher Education, 36, 33-40. https://doi.org/10.1016/j.iheduc.2017.09.002

Wahyuni, S. (2015). Developing science learning instruments based on local wisdom to improve students'critical thinking skills. Jurnal Pendidikan Fisika Indonesia. Retrieved from: http://repository.unej.ac.id/handle/123456789/ 73670

Wardani, D. N., Toenlioe, A. J. E., \& Wedi, A. (2018). Daya Tarik Pembelajaran Di Era 21 Dengan Blended Learning. Jurnal Kajian Teknologi Pendidikan (JKTP), 1(1), 13-18. Retrieved from: http://journal2.um.ac.id/index.php/jktp/article $\angle$ view $/ 2852$

Weissinger, P.A. (2003). Critical thinking skills of first-year dental students enrolled in a hybrid curriculum with a problem-based learning component. Indiana University.

Zhang, Q., \& Wu, F. (2016). Study on teacher-student interaction in flipped classroom based on video annotation learning platform. In State-of-the-art and future directions of smart learning (pp. 257-261). Springer. https:// doi.org/10.1007/978-981-287$\underline{\text { 868-7_29 }}$ 